\title{
THE IMPACT OF THE ACCOUNTING QUALITY AND INFORMATION RISK ON THE TIME OF EARNING ANNOUNCEMENT
}

\author{
Amaal Ebrahim Ahmed El-Hewety
}

\section{ABSTRACT}

$T_{\text {t }}$ risk are very important to having a significant impact on implied volatility behavior around earnings, also we aim to investigate the relationship between the quality of accounting information and the risk of accounting information and the time of announcement of the profit report,

The quality of accounting information (earnings/accruals) is one of the most widely researched areas in accounting literature. So, we examine the impact of the Accounting Quality and Information Risk on the time of Earning Announcement, we interpret our findings as indicative of information risk having a significant impact on implied volatility behavior around earnings announcements. On the other hand, risk has always been one of the concerns of management, especially in the field of financial management of companies. Considering the above-mentioned issues, Whether and how accounting information quality affects the cost of capital has been a matter of much debate.

The results show that there is a relationship between accounting information quality and accounting information risk. accounting and has been of interest to accountants, investors and financial managers. This is one of the most important topics in the field of financial and accounting research.

Keywords: Accounting Information Quality, Accounting Information Risk, Earning Announcement.

\section{INTRODUCTION:}

The continuous developments that occur in the business world in general and in the field of accounting information systems and the resulting multiple data can be processed and configured as information that can meet the quality standards and benefit to its users, which necessitated review of accounting treatments.

Due to the emergence of electronic commerce, which made financial information more complex, it became necessary to increase the knowledge of computer accountants and the Internet to adapt to the constantly changing business environment to achieve the quality of accounting. 
The role of the core business of financial reporting, the effective transfer of information to outsourced individuals in a credible and timely manner. Managers can use their knowledge of the company to improve the effectiveness of financial statements, as a means of transferring information to potential investors and potential creditors. In recent years, and especially after the financial scandals of several large companies, increasing attention has been paid to the issue of information quality. The financial statements should be designed to provide relevant and valid accounting information and to help them make effective decisions. ${ }^{1}$

Past research has associated earnings quality with idiosyncratic return volatility. This is because uncertainty about the future profitability of firms is expected to influence their stock return volatility, while the quality of earnings has been considered as a proxy for so-called 'information risk' or 'information uncertainty'. This risk refers to the likelihood for firm-specific information important for investor decisions to be of poor quality ${ }^{2}$, or the degree to which corporate value can be reasonably estimated by the most knowledgeable investors at an acceptable cost. In this direction, uncertainty about future cash flows from an operating point of view, vs. information about future cash flows stemming from the quality of accounting information and confirm that lower earnings quality is associated with higher idiosyncratic stock market volatility, even after controlling for volatility in firm operating performance ${ }^{3}$.

\section{RESEARCH PROBLEM}

The quality of financial reporting has been considered a proxy for information risk. In the presence of poor financial reporting quality, uncertainty about a firm's future profitability is expected to be high ${ }^{3}$, while, in the same direction testify that analysts indeed view firms with lower earnings quality as riskier. This is because financial reporting quality has been considered a proxy for information risk ${ }^{4}$

The information risk is increasing in 'the likelihood that firm specific information that is pertinent to investor pricing decisions is of poor quality' assume that cash flows represent the main element priced by investors, and they identify accruals quality as the measure of information risk associated with a firm's earnings.

Under the assumption that investors value securities by estimating their future cash flows, they argue in favor of making use of a measure for information risk which will capture the information uncertainty in cash flows. Given that, accruals quality should inform investors about the predictability of the mapping of accounting earnings into cash flows, with poorer accruals quality weakening this mapping and increasing information risk. In a similar that accounting

- Yarifard, Rasool and Sarmadi, Samira, The Relationship Between the Accounting Quality, Information

- Risk and Implied Volatility Around Earning Announcement (October 3, 2018). Available at SSRN: https://ssrn.com/abstract=3259809 or http://dx.doi.org/10.2139/ssrn.3259809

- Francis, J., LaFond, R. Olsson, P., and Shipper, K. (2005) 'The market pricing of accruals quality', Journal of Accounting and Economics, 39 (2), pp. 295-327.

- Anagnostopoulou, Seraina C. and Tsekrekos, Andrianos E., Accounting Quality, Information Risk and the

- Term Structure of Implied Volatility around Earnings Announcements (May 5, 2017). Research in

- International Business and Finance, Forthcoming. Available at SSRN: https://ssrn.com/abstract=2963584 ${ }^{3}$ Rajgopal, S., and M. Venkatachalam (2011) 'Financial reporting quality and idiosyncratic return volatility,', Journal of Accounting and Economics, 51(1-2), pp. 1-20.

- Ecker, F., Francis, J., Kim, I., Olsson, P., and Schipper, K. (2006) 'A returns-based representation of earnings quality', The Accounting Review, 81 (4), pp. 749-780. 
quality, or earnings quality, represents a naturally interpreted measure of information risk and because of its direct link to cash flows, which is the presumed object of investors' interest ${ }^{5}$.

As a result of the above the problem of research in the impact of the

Accounting Quality and Information Risk on the time of Earning Announcement which need to discuss this problem to contribute to the development of logical solutions to them and can be discussed through the following questions:

1- Does it affect the Accounting Quality and Information Risk on the time of Earning Announcement?

2- Does it the Accounting Quality and Information Risk affect decision-

\section{making by managers and investors?}

\section{PREVIOUS STUDIES}

Review of accounting thinking in the field of accounting for Accounting

Quality, Information Risk and the time of Earning Announcement The following relevant previous studies can be presented:

1- Anagnostopoulou (2017) ${ }^{6} \mathrm{We}$ examine the impact of accounting quality, used as a proxy for information risk, on the behavior of equity implied volatility around quarterly earnings announcements. Using US data during 1996-2010,we observe that lower (higher) accounting quality significantly relates to higher (lower) levels of implied volatility (IV) around announcements. Worse accounting quality is further associated with a significant increase in IV before announcements and is found to relate to a larger resolution in IV after the announcement has taken place. We interpret our findings as indicative of information risk having a significant impact on implied volatility behavior around earnings announcements.

This paper we refer to alternative measures of accounting quality, as well as to additional tests, that have been used to examine the robustness of our findings. None of them significantly affects the quality and direction of the findings, and we briefly describe them in this paragraph for completeness.

2-Zeyun (2016) ${ }^{\mathbf{1}}$ Building on recent market microstructure research, we decompose liquidity risk into an accounting-associated component and a nonaccounting-associated component and examine their relative importance in explaining post-earnings-announcement drift (PEAD). We find that the accounting-associated component has a stronger related to PEAD returns than is its nonaccounting- associated counterpart, suggestion that the information component of liquidity risk is important for explaining PEAD. Results of crosssectional tests reveal that the relation between accounting-associated liquidity risk and PEAD returns is weaker for firms with greater analyst following. We also find that in a significant market downturn, the relation between accounting-associated liquidity risk and PEAD returns becomes more pronounced.

2-Wells (2012) This paper investigates how the quality of accounting information

- Bhattacharya, N., Ecker, F., Olsson, P., and Schipper, K. (2012) 'Direct and mediated associations among earnings quality, information asymmetry and the cost of equity', The Accounting Review, 87 (2), pp. 449-482.

- Anagnostopoulou, Seraina C. and Tsekrekos, Andrianos E., Accounting Quality, Information Risk and the Term Structure of Implied Volatility around Earnings Announcements (May 5, 2017). Research in

- International Business and Finance, Forthcoming. Available at SSRN: https://ssrn.com/abstract=2963584 
(measured the impacts investors' reaction to announcements of financial accounting restatements. We measure investors' reaction (change in investor uncertainty about firm value) as the change in implied volatility around the event

\section{${ }^{1}$ Chen, Jeff Zeyun and Lobo, Gerald J. and Zhang, Joseph, Accounting Quality, \\ Liquidity Risk, and Post-Earnings-Announcement Drift (April 15, 2016). Available at \\ SSRN: https://ssrn.com/abstract=3002784 or http://dx.doi.org/10.2139/ssrn.3002 784}

of restatement announcements. We document that restatement announcements are associated with increases in implied volatility and that the magnitude of the change in implied volatility depends on the severity of the restatement. Next, we find evidence that firm accounting quality attenuates the relationship between change in implied volatility and restatement news. Controlling for stock returns, we find firms with high accounting quality have a lower change in implied volatility. Overall, the evidence provided in this paper suggests that the quality of a firm's accounting information impacts how investors view and interpret negative economic news leading to, on average, a smaller increase in investor uncertainty. ${ }^{7}$

\section{RESEARCH OBJECTIVES}

1-The information that is the basis of financial decisions, whether operational or investment or financing as it affects the value of the establishment and achieve a competitive advantage reflected positively on the market value of the establishment and thus increase the volume of profits and be the time to Highlight the vital role and importance of the quality of accounting information.

2- Contribute to the evaluation of the quality of accounting and financial risks and their impact in the timing of the announcement of profits.

3- Clarify The impact of the Accounting Quality and Information Risk on the time of Earning Announcement.

\section{THE IMPORTANCE OF RESEARCH}

\section{The study derives its importance from the following contributions:}

1. Research is one of the most interesting and important topics. The quality of accounting and information risk is a complex concept that opens the door to many interpretations and topics concerning the usefulness and credibility of the characteristics of accounting information.

2. The increasing attention of all professional accounting organizations in information risk, which has a significant impact on the timing of the announcement of profits and the evaluation of the best performance of organizations in this field.

3. The importance of the role played by accounting in the measurement and analysis of information risks, which helps enterprises to improve and develop continuously and support the policy of sustainable development.

4. The study was an academic attempt to highlight the Impact of the

Loktionov, Kara Wells" Does Accounting Information Affect Investor Uncertainty about Firm Value around Restatements?", http://www.aston.ac.uk/EasysiteWeb/getresource.axd?AssetID=134564\&type=Full\&servicetype=Attachm ent 
Accounting Quality and Information Risk on the time of Earning

Announcement and to assess the feasibility of using accounting information systems.

\section{RESEARCH METHODOLOGY}

In order to achieve the objectives of the study, the descriptive approach was used, the collection of data and information available from sources and processed in an objective scientific way, in order to extrapolate and classify scientific literature in the field of Accounting Quality and Information Risk,

And a theoretical aspect shows The impact of the Accounting Quality and Information Risk on the time of Earning Announcement, To reach the expected results of the study.

\section{The research will discuss the subject through several essential points:}

1. 1-accounting quality

2. Information Risk .

3. Results.

4. Recommendations

\section{1-ACCOUNTING QUALITY}

The value of financial accounting is determined largely by its quality. The central concept of accounting quality is that some accounting information is better than other accounting information at communicating what it purports to communicate. Accounting quality is thus of great interest to participants in the financial reporting supply chain. There is, however, no single, widely accepted definition of the term "accounting quality". It is interpreted differently by different individuals, organizations and industries. But in the final analysis, all definitions of account quality serve to facilitate value judgments about accounting information. Although both the FASB and IASB stress the importance of high-quality financial reports, one of the key problems found in prior literature is how to operationalize and measure this quality.

The quality of accounting earnings and accruals is one of the most actively researched areas in accounting. Over the past decades, however, the literature has made rather limited progress in measuring accounting quality. At the same time, there is a mounting criticism that the existing models of discretionary accruals do not properly control for economic performance as well as high quality accruals ${ }^{8}$

Definition: Accounting quality is the extent to which accrual accounting facilitates the measurement of the underlying economic performance. The accounting information system is defined as that structured approach, or set of structured procedures Accountant in recording and tabulating the operations of the financial institution, from the documents supporting them in the books and records Accounting for the purpose of stating the outcome of the enterprise's profit or loss and finding out the truth of its financial position at any time.

\section{Provide the necessary information to strengthen the decision-making process:}

The aim of this system is to provide useful information to management and its external beneficiaries to make decisions Internal parties This type of need is provided through the socalled management accounting as responsible For the study of the needs of the administrative

- Gerakos, Joseph; “Discussion of Detecting Earnings Management: A New Approach.” Journal of Accounting Research (2012) 1-13. 
levels and how to provide them; for the external category, most of them are provided through Published financial reports.

\section{Provide information for performance assessment:}

Accounting information produced by the accounting information system is accounting for accounting data and output in the form of financial reports the main source of the performance appraisal process, used in the process of evaluating some performance Accounting indicators that are inferred from published financial reports, from these indicators we find the profitability index, must Management should disclose its compliance with the legal responsibilities assigned to it by external parties

\section{2- INFORMATION RISK}

We begin with the assumption that information risk is multifaceted; as such, it is unlikely that quantity-based measures can capture information risk in all its aspects In principle, an informed trading equilibrium incorporates both quantity and price. By inferring informed trading from price variation, we construct an information risk measure called abnormal idiosyncratic volatility (AIV), which is the idiosyncratic volatility before an information-intensive event in excess of the idiosyncratic volatility of the normal period. The literature has long recognized that information ow is reacted in idiosyncratic volatility ${ }^{9}$. However, idiosyncratic volatility may react other features such as fundamental risk and investors' overreaction information Therefore, AIV is employed to tease out unusual price variations caused by trading activities related to information-intensive events.

\section{3-RESULTS}

- Information plays an important role in investment decision making, but the limited information that is Which are included in the interim condensed financial statements, are limited in their usefulness.

- Information affecting decision-making is not the information contained in the financial reports Just. However, other information is provided by the State and financial institutions Have a significant impact on decision-making. - firms that interested on Accounting Quality and Information Risk can choice the time of Earning Announcement that is help make good decisions.

\section{4- RECOMMENDATIONS}

- Obtain high quality financial reports in accounting information appropriate to the users of these reports.

- To invest part of the profits of the company in the development of accounting information systems, while spreading awareness of the importance of this.

- to control the risks of information and information in a timely manner to benefit from users.

- Massa, M., Zhang, B., Zhang, H., 2015. The invisible hand of short selling: does short selling disciplines earnings management? Review of Financial Studies 28, 1701-1736. 


\section{REFERENCES}

Anagnostopoulou, Seraina C. and Tsekrekos, Andrianos E., (May 5, 2017). Accounting Quality, Information Risk and the Term Structure of Implied Volatility around Earnings Announcements Research in International Business and Finance, Forthcoming. Available at SSRN: https://ssrn.com/abstract $=2963584$

- Anagnostopoulou, Seraina C. and Tsekrekos, Andrianos E., (May 5, 2017) Accounting Quality, Information Risk and the Term Structure of Implied Volatility around Earnings Announcements. Research in International Business and Finance, Forthcoming. Available at SSRN: https://ssrn.com/abstract $=2963584$

- Chen, Jeff Zeyun and Lobo, Gerald J. and Zhang, Joseph, (April 15, 2016 Accounting Quality, Liquidity Risk, and Post-Earnings-Announcement Drift). Available at SSRN: https://ssrn.com/abstract=3002784 or http://dx.doi.org/10.21 39/ssrn.3002784

- $\quad$ among earnings quality, information asymmetry and the cost of equity', The Accounting Review, 87 (2),pp. 449-482.

- $\quad$ Bhattacharya, N., Ecker, F., Olsson, P., and Schipper, K. (2012) 'Direct and mediated associations

- $\quad$ Ecker, F., Francis, J., Kim, I., Olsson, P., and Schipper, K. (2006) 'A returns-based representation of earnings quality', The Accounting Review, 81 (4), pp. 749-780.

- Francis, J., LaFond, R. Olsson, P., and Shipper, K. (2005) 'The market pricing of accruals quality',Journal of Accounting and Economics, 39 (2), pp. 295-327.

- Gerakos, Joseph (2012); "Discussion of Detecting Earnings Management: A New Approach." Journal of Accounting Research 1-13

- $\quad$ Loktionov, Kara Wells" Does Accounting Information Affect Investor Uncertainty abo ut Firm Value around Restatements?",

http://www.aston.ac.uk/EasysiteWeb/getresource.axd?AssetID=134564\&type=Full\&servi cetype $=$ Attachment

- $\quad$ Massa, M., Zhang, B., Zhang, H., 2015. The invisible hand of short selling: does short selling disciplines earnings management? Review of Financial Studies 28, 1701-1736

- Rajgopal, S., and M. Venkatachalam (2011) 'Financial reporting quality and idiosyncratic return volatility,', Journal of Accounting and Economics, 51(1-2), pp. 1-20.

- Yarifard, Rasool and Sarmadi, Samira, The Relationship Between the Accounting Quality, Information Risk and Implied Volatility Around Earning Announcement (October 3, 2018). Available at SSRN: https://ssrn.com/abstract $=3259809$ or http://dx.doi.org/10.2139/ssrn.3259809 